\title{
Effects of Remote Stimulation on the Mean Firing Rate of Cat Retinal Ganglion Cells
}

\author{
Christopher L. Passaglia,, ${ }^{1,2}$ Christina Enroth-Cugell, ${ }^{1}$ and John B. Troy ${ }^{1}$ \\ ${ }^{1}$ Department of Biomedical Engineering, Northwestern University, Evanston, Illinois 60208, and 2Department of \\ Ophthalmology, Northwestern University, Chicago, Illinois 60611
}

Visual stimulation outside the classical receptive field can have pronounced effects on cat retinal ganglion cells. We characterized the effects of such stimulation by varying the contrast, spatial frequency, temporal frequency, and spatial extent of remote drifting sinusoidal gratings. We found that the mean firing rate of some $X$-cells and most $Y$-cells increased to remote gratings of low spatial frequency and high temporal frequency and decreased to ones of high spatial frequency and low temporal frequency. At least $10-20 \%$ contrast was required to see either effect, which quickly saturated at higher contrasts. Both effects were substantial, raising or lowering the mean rate of some cells by over 40 impulses/sec. Classical receptive field mechanisms were not involved because the remote gratings caused little or no response modulation. We conclude that, in addition to a mean-increasing mechanism known from previous work, a mean-decreasing one operates in the cat retina. This

A complete description of the receptive field properties of visual neurons is essential for understanding their function in perception. Classical investigations of retinal ganglion cell receptive fields emphasized their linear center-surround organization (Barlow, 1953; Kuffler, 1953). Consequently, the discharge pattern of mammalian ganglion cells is commonly thought to encode the arithmetic sum of signals from these two mutually antagonistic mechanisms (Rodieck, 1965; Enroth-Cugell and Robson, 1966). Often overlooked are nonlinear mechanisms operating both inside and outside the classical receptive field.

A key insight into nonclassical receptive field mechanisms was the discovery of rectifying subunits (Hochstein and Shapley, 1976b), approximately the size of the receptive field center of X-cells in cat (So and Shapley, 1981; Enroth-Cugell and Freeman, 1987). The subunits are thought to underlie several nonlinear aspects of ganglion cell behavior, such as their frequency-doubled response to contrast-reversing gratings and mean-rate increase to drifting gratings (Enroth-Cugell and Robson, 1966; Hochstein and Shapley, 1976b). The retina pools subunit signals over widespread regions and relays the result mainly to Y-cells (Hochstein and Shapley, 1976a) and Q-cells (Troy et al., 1995) in cat and M-cells in monkey (Benardete and Kaplan, 1999). The pooled

\footnotetext{
Received March 5, 2001; revised May 15, 2001; accepted May 16, 2001.

This work was supported by National Institutes of Health National Eye Institute Grants F32-EY06908, T32-EY07128, and R01-EY06669. We thank Drs. Jennifer Kang-Derwent and Lissa Silver for technical assistance and two anonymous referees for their helpful comments and suggestions.

Correspondence should be addressed to Dr. Christopher L. Passaglia, Department of Biomedical Engineering, Northwestern University, 2145 Sheridan Road, Evanston, IL 60208. E-mail: passaglia@northwestern.edu.

Copyright (c) 2001 Society for Neuroscience 0270-6474/01/215794-10\$15.00/0
}

mechanism prefers slower motion and resolves finer patterns than the mean-increasing one. We incorporate these findings into a model consisting of pools of small and large rectifying subunits of opposite polarity. Model estimates of subunit radius were primarily independent of eccentricity and averaged $\sim 0.15$ and $\sim 0.60^{\circ}$ for the mean-decreasing and mean-increasing mechanisms, respectively. This makes the subunits approximately the center size of central X- and Y-cells. Because smooth movements of the eyes, head, or body should engage these mechanisms under natural conditions, we propose that the mean rate changes that would ensue are functionally relevant to cat vision.

Key words: cat; $X$ - and $Y$-cells; receptive field; nonlinear subunits; contrast gain control; shift effect; periphery effect; maintained discharge signal may provide the neural measure of contrast used by retinal contrast gain controls to modulate the transfer characteristics of ganglion cells (Shapley and Victor, 1978; Victor, 1987).

Despite such valuable insights, the nonclassical receptive field remains somewhat enigmatic because previous studies have generated apparent inconsistencies regarding the polarity of subunit signals. Most mammalian studies have reported that continuous motion of remote stimulus patterns increases the ganglion cell firing rate (Levick et al., 1964; McIlwain, 1964; Ikeda and Wright, 1972) and that sudden motion elicits transient bursts of spikes (Krüger and Fischer, 1973; Noda and Adey, 1974; Barlow et al., 1977). This implies that nonlinear subunits excite ganglion cells. However, remote stimulation has also been seen to decrease the mean rate (Caldwell and Daw, 1978; Enroth-Cugell and Jakiela, 1980; Krüger, 1980) or to transiently interrupt spiking (Cleland and Levick, 1974; Watanabe and Tasaki, 1980; Rapaport and Stone, 1988). This instead argues that the subunits inhibit ganglion cells, as they apparently do in mudpuppy (Werblin, 1972; Werblin and Copenhagen, 1974; Thibos and Werblin, 1978) and turtle (Schwartz, 1973). Lending additional support for inhibitory subunits in mammals, most studies have reported that remote stimulation suppresses ganglion cell responses to flashing spots centered in their receptive field (Cleland and Levick, 1974; Shapley and Victor, 1979; Enroth-Cugell and Jakiela, 1980). But, response enhancements have also been seen (McIlwain, 1964; Ikeda and Wright, 1972; Krüger, 1980). Perhaps the retina uses multiple subunit types having different influences on ganglion cells.

Our results support this hypothesis. We show that the mean firing rate of $\mathrm{X}$ - and $\mathrm{Y}$-cells increases or decreases depending on 
the spatiotemporal characteristics of remote stimulus patterns, indicating that both excitatory and inhibitory nonlinear mechanisms are at work in cat retina. These findings help clarify the functional organization of the nonclassical receptive field and its effects on mammalian ganglion cells.

\section{MATERIALS AND METHODS}

Animal preparation. Retinal ganglion cell discharges were recorded extracellularly from anesthetized and paralyzed adult male cats. A detailed description of the experimental procedures has been provided elsewhere (Troy and Robson, 1992). Briefly, general anesthesia was induced with an intravenous injection of a short-acting barbiturate (sodium thiopental, 20 $\mathrm{mg} / \mathrm{kg}$ ) or, on a few occasions, with an intramuscular injection of ketamine $(25 \mathrm{mg} / \mathrm{kg})$ mixed with acepromazine $(1 \mathrm{mg} / \mathrm{kg})$. Supplemental doses of sodium thiopental $(2-3 \mathrm{mg} / \mathrm{kg})$ were given as needed to maintain a surgical level of anesthesia until transition was made to a longacting anesthetic (ethyl carbamate). Ethyl carbamate, which was inf used continually during the experiment $\left(15-50 \mathrm{mg} \cdot \mathrm{kg}^{-1} \cdot \mathrm{hr}^{-1}\right)$, is well suited for long-term recording because of its prolonged duration of action and minimal depression of cardiac output (Flecknell, 1996).

After a stable plane of anesthesia was reached, as assessed by standard methods (e.g., lack of pedal withdrawal and eye blink reflexes), eye movements were minimized by continually infusing a paralytic agent (pancuronium bromide, $0.2 \mathrm{mg} \cdot \mathrm{kg}^{-1} \cdot \mathrm{hr}^{-1}$, or gallamine triethiodide, $10 \mathrm{mg} \cdot \mathrm{kg}^{-1} \cdot \mathrm{hr}^{-1}$ ). After paralysis, the animal was artificially respirated, and records of its blood pressure and heart rate were monitored to titrate the dosage rate of anesthetic. Body temperature and end-tidal $\mathrm{CO}_{2}$ were also tracked throughout the experiment and kept at physiological levels. In addition to anesthetic and paralytic agents, the animal was administered dexamethasone acetate $(4 \mathrm{mg})$, atropine sulfate $(0.3$ $\mathrm{mg}$ ), and cefazolin sodium (100 mg every $12 \mathrm{hr}$ ) via intramuscular injection. Ophthalmic solutions of atropine and phenylephrine hydrochloride were periodically instilled into the eyes to dilate the pupils and retract the nictitating membranes. Contact lenses with 4-5 mm artificial pupils were fitted bilaterally, and spectacle lenses were added to the optical path as necessary to focus the stimulus onto the retina.

Visual stimulation. Visual stimuli were displayed on a Sony Trinitron color monitor (Multiscan 17se) running at $150 \mathrm{~Hz}$. The monitor was controlled by an IBM-compatible 80486 computer via a pattern generation card (VSG2/2; Cambridge Research Systems). The animal viewed the 30 by $22.5 \mathrm{~cm}$ display of the monitor at a distance of $\sim 60 \mathrm{~cm}$ through an adjustable mirror. The field of stimulation thus spanned a $30^{\circ}$ by $20^{\circ}$ region of space. The product of display luminance $\left(30 \mathrm{~cd} / \mathrm{m}^{2}\right)$ and pupil area resulted in a retinal illuminance of $\sim 500$ cat trolands (Troy et al., 1999), which lies in the photopic range of the animal.

Data collection. Recordings of ganglion cell discharges were made in vivo from the optic tract or retinal surface with tungsten-in-glass microelectrodes (Levick, 1972). Times of spike discharge were collected, together with stimulus synchronization pulses, by the 80486 computer via a data acquisition card (AS-1; Cambridge Research Systems) and custom software (Bohnsack and Troy, 1997). The retinal location of a recorded cell was determined by plotting its receptive field center on a tangent screen onto which the optic disk and major blood vessels surrounding the area centralis were also drawn. The receptive field was then projected onto the stimulus display and centered by adjusting the mirror horizontally and vertically until the response of the cell to a contrast-reversing bipartite field contained no component at the frequency of reversal (Enroth-Cugell and Robson, 1966).

Data collection started after the cell was centered on the display. First, maintained discharges were collected under full-field steady uniform illumination for 30-120 sec. This specified the resting rate of the cell. Next, full-field sinusoidal gratings of different spatial frequency [0.02-4 cycles per degree (cpd)] were successively drifted at $2 \mathrm{~Hz}$ across the display. The contrast of the gratings was adjusted until the amplitude of the response component at the fundamental frequency $(2 \mathrm{~Hz})$ was in the range of 5-10 impulses/sec (ips), where amplitude scales linearly with contrast (Troy and Enroth-Cugell, 1993). Grating contrast $C$ was defined as:

$$
C=\frac{L_{\mathrm{MAX}}-L_{\mathrm{MIN}}}{L_{\mathrm{MAX}}+L_{\mathrm{MIN}}} \times 100 \%,
$$

where $L_{\mathrm{MAX}}$ and $L_{\mathrm{MIN}}$ are the maximum and minimum luminance of the grating, respectively. In some cases, full-field contrast-reversing gratings

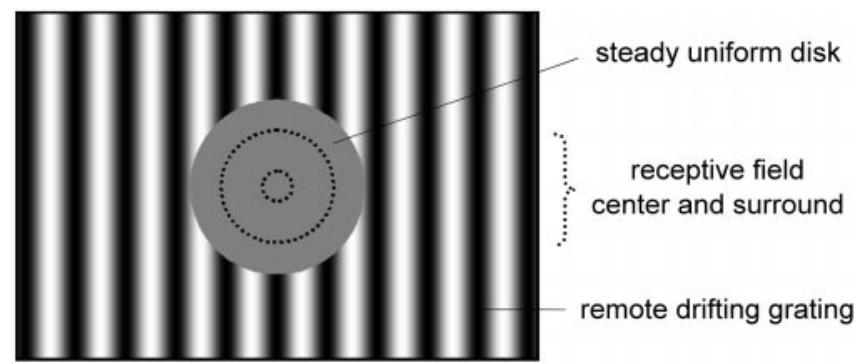

Figure 1. Visual stimulus. A large steady uniform disk overlying the receptive field center and surround (dashed lines) restricted a drifting sinusoidal grating to regions outside the classical receptive field of recorded ganglion cells. Field of grating stimulation, $30^{\circ} \times 20^{\circ}$.

were also used. The contrast of these gratings was adjusted until the second-harmonic component $(4 \mathrm{~Hz})$ was in the 5-10 ips range. Fundamental (and second-harmonic) responsivities were then computed by dividing response amplitude at each spatial frequency by grating contrast (Enroth-Cugell et al., 1983). The resulting curves were fitted in the spatial frequency domain with a difference-of-Gaussian model (Rodieck, 1965; Enroth-Cugell and Robson, 1966), which yielded an estimate of receptive field center and surround radii, $R_{\mathrm{C}}$ and $R_{\mathrm{S}}$, and responsivities, $K_{\mathrm{C}}$ and $K_{\mathrm{S}}$. On the basis of the radius estimates, the portion of the grating overlying the classical receptive field of the cell was replaced by a large steady uniform disk having the same mean luminance as the grating (Fig. 1). The disk prevented the grating from stimulating the receptive field center and much, if not all, of the surround. A $10^{\circ}$ disk was generally sufficient for this purpose, but some Y-cells required even larger disks to eliminate modulated responses to the grating (Troy et al., 1993). Effects of remote stimulation were then investigated by computing peristimulus time histograms (PSTHs) of the instantaneous firing rate while varying the spatial frequency $(0.05-4 \mathrm{cpd})$, temporal frequency $(0.25-16 \mathrm{~Hz})$, or contrast $(5-80 \%)$ of the grating or the diameter of the disk $\left(5-20^{\circ}\right)$. PSTHs were typically constructed from $30 \mathrm{sec}$ epochs of spike discharge. Dividing the number of impulses accumulated in each bin by the bin width and the number of stimulus cycles yielded the average instantaneous rate of the cell. Before each epoch of data collection, the mean firing rate was allowed to recover to its resting value. This could take up to $90 \mathrm{sec}$ depending on the remote stimulus and the cell.

Cell sample. The various ganglion cell types were distinguished by four main criteria: the size and responsivity of their receptive field centers, the shape of the interval histogram of their maintained discharges, and their response to contrast-reversing gratings of high spatial frequency. $\mathrm{X}$-cells were identified by their relatively small centers and high rate of maintained discharge. Y-cells were identified by their greater responsivity and large second-harmonic response to reversing gratings. Q-cells and other known types of W-cell were excluded from analysis. Data reported here were collected from $60 \mathrm{X}$-cells and $80 \mathrm{Y}$-cells across 19 cats. The cells ranged from 3 to $43^{\circ}$ in eccentricity.

\section{RESULTS}

\section{Mean firing rate of ganglion cells depends on the spatiotemporal pattern of remote stimulation}

The continuous motion of high contrast patterns outside the classical receptive field is known to increase the mean firing rate of ganglion cells (Levick et al., 1964; McIlwain, 1964; Ikeda and Wright, 1972; Moors et al., 1974; Enroth-Cugell and Jakiela, 1980; Fischer and Krüger, 1980), but exceptions exist (EnrothCugell and Jakiela, 1980; Krüger, 1980; Rapaport and Stone, 1988). The reason for these exceptions remains unclear, so we characterized the effect of remote stimulation in systematic detail using drifting sinusoidal gratings as illustrated in Figure 1. Figure $2 a$ plots the responses of an ON-center Y-cell to remote gratings of different spatial frequency drifting at $4 \mathrm{~Hz}$. The gratings had a pronounced effect on mean rate, raising and lowering it by up to $\sim 50 \%$ of its resting value (dotted lines) as spatial frequency was varied (Fig. $2 c$ ). The gratings did not, however, evoke a response 
a

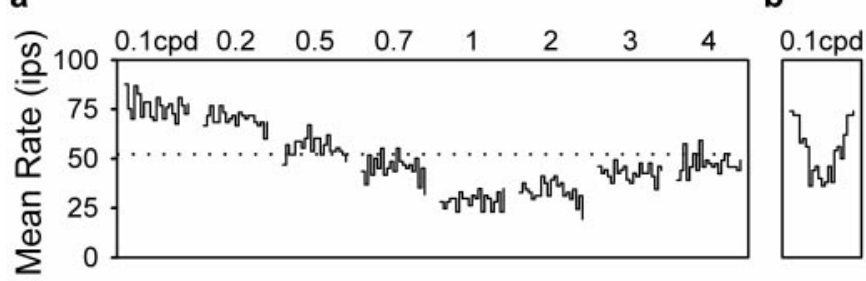

C

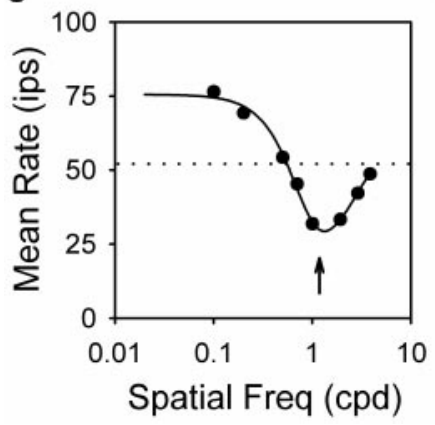

d

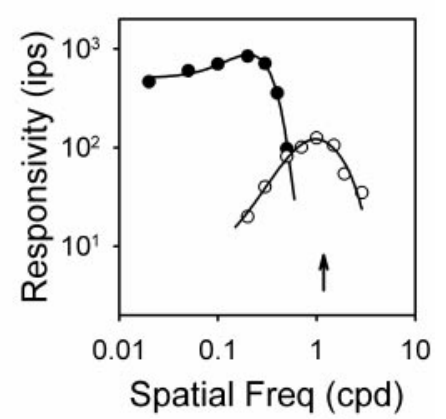

Figure 2. Remote stimulation changes the mean firing rate of ganglion cells. $a$, PSTHs of the response of an ON-center Y-cell (3005) to remote gratings of different spatial frequency drifting at $4 \mathrm{~Hz}$. Each waveform is $0.25 \mathrm{sec}$ in duration. Disk diameter, $15^{\circ}$; grating contrast, $50 \%$. $b$, PSTH of the response of the cell to a full-field grating drifting at $4 \mathrm{~Hz}$. Scales are the same as in $a$. Grating contrast and spatial frequency, $5 \%$ and $0.1 \mathrm{cpd}$, respectively. $c$, Mean rate of the cell as a function of spatial frequency. The solid line is the best fit of the dual-subunit model (see Fig. 5) to the data. Parameters of the fit are $K_{\mathrm{E}}=55$ ips, $K_{\mathrm{I}_{\mathrm{C}}}=33 \mathrm{ips}, R_{\mathrm{E}}=0.45^{\circ}$, and $R_{\mathrm{E}_{\mathrm{C}}}=0.11^{\circ}$. Dotted lines in $a$ and $c$ indicate the resting rate of the cell for steady uniform full-field illumination. $d$, Spatial frequency curves of the first-harmonic ( filled circles) and second-harmonic (open circles) response of the cell to full-field drifting and contrast-reversing gratings, respectively. Responsivity is the response amplitude at each spatial frequency divided by the contrast required to evoke it. Solid lines give the best fit of a difference-of-Gaussian model (Rodieck, 1965; Enroth-Cugell and Robson, 1966) to the data. Parameters of the first- and second-harmonic fits are $K_{\mathrm{C}}=1500$ and $161 \mathrm{ips}, K_{\mathrm{S}}=1015$ and $154 \mathrm{ips}, R_{\mathrm{C}}=0.95$ and $0.15^{\circ}$, and $R_{\mathrm{S}}=2.10$ and $0.54^{\circ}$, respectively. Freq, Frequency.

component at the drift frequency, although they were high (50\%) in contrast. This was not because the cell was unresponsive to grating stimulation. Removing the disk overlaying the receptive field center and surround produced strongly modulated responses using much less contrast (Fig. 2b). Because remote stimulation changed the mean firing rate without significantly modulating the rate, nonlinear mechanisms must be involved.

Is it possible that the nonlinearity resides within the classical receptive field? Although the center and surround have traditionally been regarded as linear mechanisms, they do show some saturation at high stimulus contrast (Enroth-Cugell and Robson, 1966; Troy and Enroth-Cugell, 1993) that could cause the mean rate to change. Center saturation could not have factored into our experiments because of the stimulus configuration. But, the disk may not have entirely masked the grating from the surround, which can be quite large in Y-cells (Troy et al., 1993). To examine the possibility of surround saturation, Figure $2 d$ plots as filled circles the spatial frequency curve of the fundamental component of the response of the cell to full-field drifting gratings. Note that the cell had high contrast sensitivity, as evidenced by its peak responsivity of $\sim 1000$ at $0.3 \mathrm{cpd}$. This is typical of Y-cells. Responsivity fell rapidly at higher spatial frequencies, as the spatial resolution of the center was exceeded, and declined at lower spatial frequencies, as the surround became increasingly active. Comparison of the fundamental tuning curve with Figure $2 c$ reveals that remote gratings lowered the mean rate at spatial frequencies that the center could not even resolve. Because linear summation of positive and negative signals would produce no net surround output at such high spatial frequencies, the mean rate change could not have resulted from saturation of the surround output. Maybe the retinal elements providing input to the surround saturated. An asymmetric distortion of their waveforms would, in fact, produce a sustained surround component after spatial pooling and thus a decrease in ganglion cell firing rate without a modulation in rate at high spatial frequency. Although promising, this explanation predicts that lowering spatial frequency would increasingly drive surround inputs in synchrony and generate modulated responses much larger than any mean rate change. As noted above, the cell showed little or no response modulation to a $0.1 \mathrm{cpd}$ remote grating of high contrast. A modulated component should have been evident if the gratings overlaid much of the surround because surround responsivity at this spatial frequency reached $75 \%$ of its maximum value according to difference-of-Gaussian fits of the fundamental tuning curve (Fig. $2 d$, solid line). We therefore discount the possibility that classical receptive field mechanisms caused the mean rate changes.

More likely candidates are the rectifying subunits of Hochstein and Shapley (1976b). These nonlinear retinal elements are part of a mechanism extending beyond the limits of the receptive field center and surround that is considered responsible for generating the second-harmonic response of ganglion cells to contrastreversing gratings (Enroth-Cugell and Robson, 1966; Hochstein and Shapley, 1976b) and their "shift response" to remote patterns that suddenly move (Krüger and Fischer, 1973; Barlow et al., 1977; Derrington et al., 1979). They may have been involved in the mean rate changes described here to remote drifting gratings, but this remains to be shown. The mean rate changes could have instead resulted from other nonlinear subunits or mechanisms operating in the retina. We will therefore treat the frequencydoubling and mean-changing mechanisms as separate entities and refer to their respective subunits as frequency-doubling subunits and mean-changing subunits. Figure $2 a$ indicates that there are at least two types of mean-changing subunit, one that increases ganglion cell firing rate and one that decreases it. Two subunit types are implied because the polarity of mean rate changes induced by a single type would not depend on the spatiotemporal pattern of stimulation. Moreover, some cells only increased their mean rate in response to remote drifting gratings (see below).

To explore possible relationships between the frequencydoubling and mean-changing subunits, the open circles in Figure $2 d$ plot the spatial frequency curve of the second-harmonic response of the cell to full-field reversing gratings. Like similar curves reported previously (Hochstein and Shapley, 1976b; So and Shapley, 1981; Freeman, 1991), it peaked at a higher spatial frequency than did the fundamental tuning curve. More important, the peak of the curve corresponded well to that of the mean rate curve over the range of spatial frequencies that rate decreased (Fig. $2 c, d$, arrows). This suggests that frequency-doubling subunits are related to mean-decreasing subunits and not to mean-increasing subunits, contrary to what one might expect.

Figure 3 summarizes the effect of remote drifting gratings on the ensemble of recorded ganglion cells. Filled and open circles plot, as a function of the resting rate of the cells, their mean rate for a 0.1 and $1 \mathrm{cpd}$ remote grating, respectively, of $50 \%$ contrast 


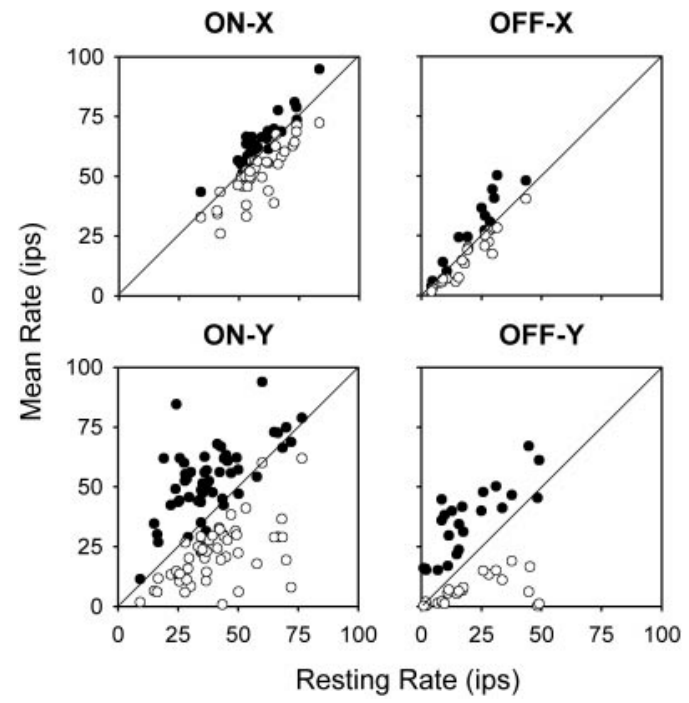

Figure 3. Remote stimulation affects Y-cells more than X-cells. Plotted against their resting firing rate are the mean rates of recorded $\mathrm{ON}$ - and OFF-center X-cells $[n=38(O N-X), 21(O F F-X)]$ and Y-cells $[n=54$ $(O N-Y), 24(O F F-Y)]$ for a $0.1 \mathrm{cpd}$ ( filled circles) and $1 \mathrm{cpd}$ (open circles) remote grating drifting at $1 \mathrm{~Hz}$. Diagonal lines indicate no change in firing rate. Disk diameter, $10-15^{\circ}$; grating contrast, $50 \%$. Note that some cells were not tested with both gratings and that OFF cells having little or no resting discharge were often discarded because inhibitory effects were impossible to measure from them.

drifting at $1 \mathrm{~Hz}$. These particular spatial frequencies were chosen because the former tended to increase mean rate and the latter tended to decrease it (Fig. $2 b$ ). The scatter of points reflects differences in the resting rate and in the magnitude and frequency dependence of the remote effect across cells. Points on the diagonal indicate cells that were unaffected by the grating. Many $\mathrm{X}$-cells fell into this category, but there were some that showed substantial elevations or reductions in mean rate. The average rate change for 0.1 and $1 \mathrm{cpd}$ gratings drifting at $1 \mathrm{~Hz}$ was $5.2 \pm$ 3.9 ips (mean \pm SD) and $-6.0 \pm 6.2$ ips for ON-center X-cells and $6.1 \pm 5.8$ and $-3.5 \pm 3.1$ ips for OFF-center X-cells, respectively. Larger effects were commonly seen in Y-cells, as evidenced by the numerous points above and below the diagonal. There were also few crossover points, confirming that the two spatial frequencies had opposite effects on mean rate. The average rate change for 0.1 and $1 \mathrm{cpd}$ gratings drifting at $1 \mathrm{~Hz}$ was $15.4 \pm 13.2$ and $-18.3 \pm 13.1 \mathrm{ips}$ for ON-center Y-cells and $16.1 \pm 9.3$ and $-14.2 \pm 14.6$ ips for OFF-center Y-cells, respectively. Besides demonstrating that $\mathrm{Y}$-cells showed greater effects than did $\mathrm{X}$-cells, the numbers indicate that $\mathrm{ON}$ - and OFF-center cells showed approximately the same effect. We therefore derived the results to follow from ON- and OFF-center Y-cells, pooling them together for group averages. X-cells showed the same basic effects but smaller in magnitude and frequency.

\section{Mean-changing subunits have different spatiotemporal properties}

Remote effects on ganglion cell activity exhibited a characteristic dependence on spatiotemporal frequency. Figure 4 plots, from top to bottom, spatial and temporal frequency curves of the mean rate for a typical Y-cell, one that showed mainly rate increases, and one that showed mainly rate decreases and the average curves for a sample of 13 Y-cells. Considering first spatial frequency curves of the typical cell (Fig. $4 a$, left) or the group average (Fig.
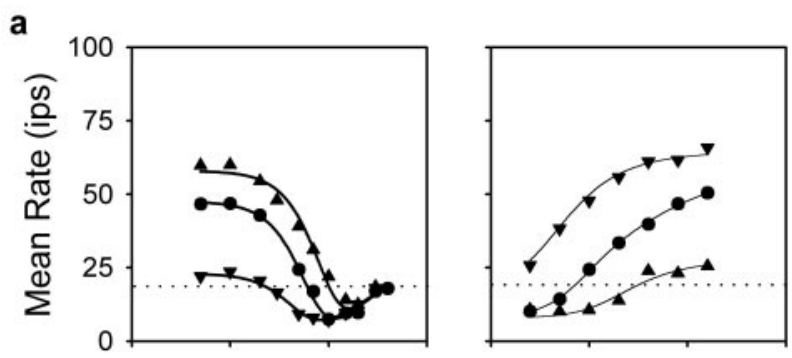

b
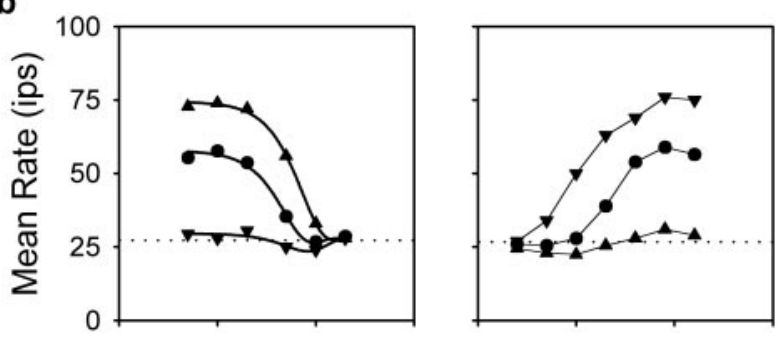

C
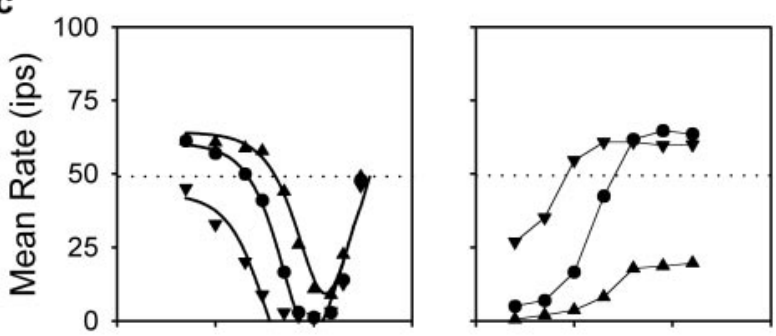

d
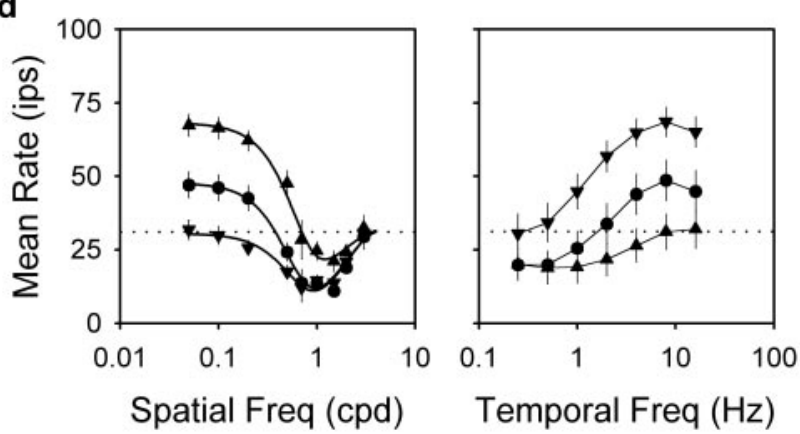

Figure 4. Spatiotemporal characteristics of the mean-changing subunits. Left, Spatial frequency curves of the mean rate for remote gratings of 0.25 $\mathrm{Hz}$ (downward triangles), $1 \mathrm{~Hz}$ (circles), and $4 \mathrm{~Hz}$ (upward triangles) for two OFF-Y-cells $(a, 2908 ; c, 3003)$, an ON-Y-cell $(b, 2917)$, and a group of 13 Y-cells ( $d$; average curves). Error bars indicate SEMs. Thick lines give the best fit of the dual-subunit model (see Fig. 5) to the data. Parameters of the fits in $a-c$ for the $1 \mathrm{~Hz}$ grating are $K_{\mathrm{E}}=39,30$, and 69 ips; $K_{\mathrm{I}_{\mathrm{C}}}=13,0$, and $78 \mathrm{ips} ; R_{\mathrm{E}}=0.56,0.73$, and $0.60^{\circ}$; and $R_{\mathrm{I}_{\mathrm{C}}}=0.13$, indeterminate, and $0.15^{\circ}$, respectively. Those for the 0.25 and $4 \mathrm{~Hz}$ grating are not provided to conserve space. Parameters for group average fits are listed in Table 1. Right, Temporal frequency curves of the mean rate for remote gratings of $0.1 \mathrm{cpd}$ (downward triangles), $0.5 \mathrm{cpd}$ (circles), and 1 cpd (upward triangles) for the three cells $(a-c)$ and the group average $(d)$. Thin lines connect data points of common spatial frequency. Dotted lines give the resting rate of the three cells and the average resting rate for the group of cells. Disk diameter, $10-15^{\circ}$; grating contrast, $50 \%$.

$4 d$, left), mean rate typically fell below the resting rate for remote gratings in the range of $\sim 0.5$ to $\sim 3 \mathrm{cpd}$. This indicates that mean-decreasing subunits cannot resolve spatial frequencies much higher than $3 \mathrm{cpd}$. Their effect was most evident at low drift frequencies $(0.25 \mathrm{~Hz}$, downward triangles). Moderate drift fre- 
quencies $(1 \mathrm{~Hz}$, circles) revealed the mean-increasing subunits that drove the mean rate above rest at low spatial frequencies (below $\sim 0.5 \mathrm{cpd}$ ). At higher drift frequencies $(4 \mathrm{~Hz}$, upward triangles), they elevated the mean rate even further.

Parallel effects are seen, from a slightly different point of view, in temporal frequency curves of the mean rate for the typical cell (Fig. 4a, right) and the group average (Fig. 4d, right). For remote gratings of low spatial frequency $(0.1 \mathrm{cpd}$, downward triangles $)$, the mean rate was elevated at nearly every temporal frequency. Those above $\sim 1 \mathrm{~Hz}$ caused the largest rate increase, indicating that mean-increasing subunits respond best to high drift frequencies. Mean-decreasing subunits, on the other hand, respond best to low drift frequencies as evidenced by the drop in mean rate for high spatial frequency gratings ( $1 \mathrm{cpd}$, upward triangles) of $\sim 2 \mathrm{~Hz}$ or less. For gratings of intermediate spatial frequency $(0.5 \mathrm{cpd}$, circles), the mean rate decreased or increased depending on which of the two mean-changing mechanisms was more active at a given drift frequency.

Remote gratings did not affect all cells in the same manner as the typical one. A few X-cells (4 of 12) and Y-cells (2 of 27) received input almost exclusively from mean-increasing subunits because high spatial frequency gratings did not lower the mean rate (Fig. $4 b$ ). The spatial frequency cutoff of their mean ratetuning curves was $\sim 0.3 \mathrm{cpd}$, indicating that mean-increasing subunits must be larger than mean-decreasing ones because the latter respond out to $\sim 3 \mathrm{cpd}$. This is important because it eliminates other interpretations of our results. For example, the meanincreasing subunits could have been as small as the meandecreasing ones, but the latter more potent and bandpass in spatial frequency. On the basis of the shape of the tuning curves, we surmise that mean-increasing subunits behave as low-pass spatial filters and high-pass temporal filters over the frequency range of our measurements. At the other extreme were some Y-cells (5 of 27) that received stronger than typical input from the mean-decreasing mechanism (Fig. 4c). All of the cells were silenced by remote gratings of high spatial frequency and low temporal frequency. Spatial frequency curves of their mean rate were markedly bandpass, even for slow-moving gratings that should not have activated the mean-increasing mechanism (Fig. 4b, right). This implies that mean-decreasing subunits have center-surround organization. Their surround appears to be approximately the same size as a mean-increasing subunit. Frequency-doubling subunits are thought to have center-surround organization as well (Victor and Shapley, 1979; Enroth-Cugell and Freeman, 1987). This is evidenced by the bandpass shape of the second-harmonic curve in Figure $2 d$ and lends additional support to the previous notion that frequency-doubling subunits and mean-decreasing subunits may be related. We infer from such cells that the meandecreasing subunits behave as bandpass spatial filters and, on the basis of temporal tuning curves for high spatial frequency gratings, as low-pass temporal filters over the frequency range of our measurements.

\section{A model of the mean-changing mechanisms}

These qualitative descriptions of mean-increasing and meandecreasing subunits were incorporated into a quantitative model of the mean-changing mechanisms (Fig. 5). This model attributes mean rate changes to the balance of interaction between an excitatory and an inhibitory nonlinear mechanism providing input to ganglion cells. The mechanisms are nonlinear because they convert periodic input into a constant output. They do this by rectifying and then pooling signals from many large or small

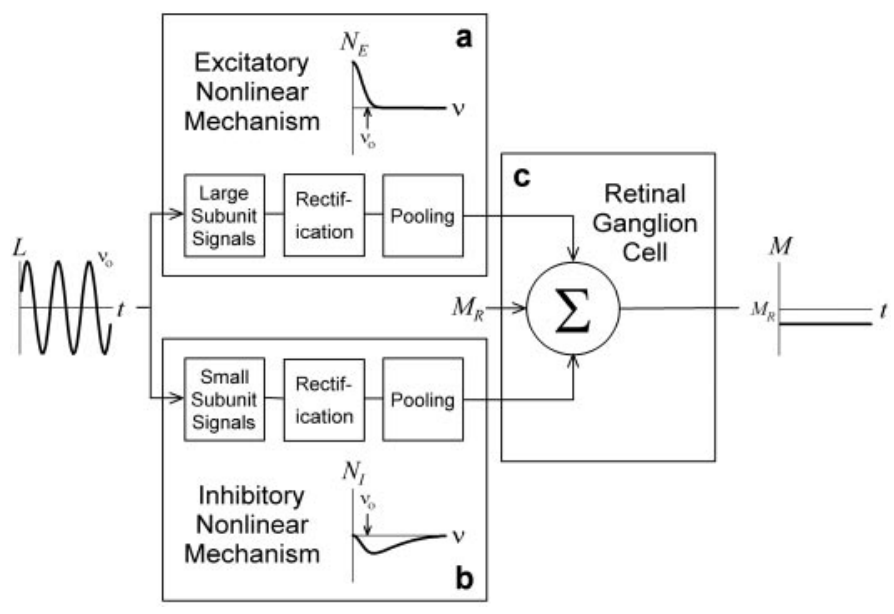

Figure 5. A model of the mean-changing mechanisms. Moving from left to right, the figure depicts the luminance modulation at a point in space caused by a remote drifting grating of spatial frequency $\nu_{\mathrm{o}}$ (leftmost plot). The high contrast stimulus activates excitatory and inhibitory nonlinear mechanisms that rectify and pool signals from many large or small subunits distributed across the retina (boxes $a, b$ ). If $\nu_{\mathrm{o}}$ is sufficiently high, the grating will asynchronously activate the subunits, and their pooled output will be essentially constant. The magnitude of the large subunit output $N_{\mathrm{E}}$ is modeled as a Gaussian function of spatial frequency (inset a), and the magnitude of the small subunit output $N_{\mathrm{I}}$ is modeled as the difference of two Gaussian functions (inset $b$ ). Ganglion cells combine input from mean-increasing and mean-decreasing mechanisms with the signal $M_{\mathrm{R}}$ that sets their resting firing rate in steady uniform illumination (box c). Consequently, their mean rate $M$ increases or decreases depending on which mechanism is more active at a given spatial frequency. Because the grating resides outside the receptive field center and surround, no modulated component would be evident in their response (rightmost plot).

subunits. The large (mean-increasing) subunits are part of the excitatory mechanism and have spatial frequency profiles shaped as a Gaussian function. The small (mean-decreasing) subunits are part of the inhibitory mechanism and have spatial frequency profiles shaped as the difference of two Gaussian functions. That is, they have center-surround organization. Their surround is the same size as the center of a large subunit. Note that this does not necessarily mean that the large subunits are excitatory and the small ones inhibitory because the subunits may exert their effect on ganglion cells indirectly via other cells.

Because drifting gratings of sufficiently high spatial frequency will activate the subunits asynchronously, the output of the excitatory $N_{\mathrm{E}}$ and inhibitory $N_{\mathrm{I}}$ nonlinear mechanisms will be constant and given by:

$$
\begin{gathered}
N_{\mathrm{E}}(v, f)=K_{\mathrm{E}_{\mathrm{c}}}(f) \exp \left(-\pi^{2} v^{2} R_{\mathrm{E}_{\mathrm{c}}}(f)^{2}\right) \\
N_{\mathrm{I}}(v, f)=-K_{\mathrm{I}_{\mathrm{c}}}(f) \exp \left(-\pi^{2} v^{2} R_{\mathrm{I}_{\mathrm{c}}}(f)^{2}\right) \\
+K_{\mathrm{I}_{\mathrm{s}}}(f) \exp \left(-\pi^{2} v^{2} R_{\mathrm{I}_{\mathrm{s}}}(f)^{2}\right),
\end{gathered}
$$

where $v$ and $f$ are the spatial and temporal frequency of the remote grating. $K_{\mathrm{E}_{\mathrm{C}}}, K_{\mathrm{I}_{\mathrm{C}}}$, and $K_{\mathrm{I}_{\mathrm{S}}}$ are the integrated strengths of large subunits, small subunit centers, and small subunit surrounds, respectively, expressed in terms of the maximal change in ganglion cell firing rate that they can induce. $R_{\mathrm{E}_{\mathrm{C}}}, R_{\mathrm{I}_{\mathrm{C}}}$, and $R_{\mathrm{I}_{\mathrm{S}}}$ are the Gaussian radii of large subunits, small subunit centers, and small subunit surrounds, respectively. Because $R_{\mathrm{E}_{\mathrm{C}}}$ and $R_{\mathrm{I}_{\mathrm{S}}}$ are equal, the net output $N$ of the two nonlinear mechanisms is given by: 


\begin{tabular}{|c|c|c|c|}
\hline Parameters & $0.25 \mathrm{~Hz}$ & $1 \mathrm{~Hz}$ & $4 \mathrm{~Hz}$ \\
\hline$K_{\mathrm{E}}$ & $\begin{array}{c}26 \text { ips } \\
(23 \pm 4)\end{array}$ & $\begin{array}{c}42 \text { ips } \\
(42 \pm 5)\end{array}$ & $\begin{array}{c}52 \text { ips } \\
(58 \pm 6)\end{array}$ \\
\hline$R_{\mathrm{E}}$ & $\begin{array}{c}0.58^{\circ} \\
(0.66 \pm 0.06)\end{array}$ & $\begin{array}{c}0.61^{\circ} \\
(0.68 \pm 0.07)\end{array}$ & $\begin{array}{c}0.53^{\circ} \\
(0.49 \pm 0.05)\end{array}$ \\
\hline$K_{\mathrm{I}_{\mathrm{c}}}$ & $\begin{array}{c}27 \text { ips } \\
(24 \pm 4)\end{array}$ & $\begin{array}{c}26 \text { ips } \\
(25 \pm 5)\end{array}$ & $\begin{array}{c}15 \text { ips } \\
(20 \pm 6)\end{array}$ \\
\hline$R_{\mathrm{I}_{\mathrm{c}}}$ & $\begin{array}{c}0.15^{\circ} \\
(0.16 \pm 0.01)\end{array}$ & $\begin{array}{c}0.15^{\circ} \\
(0.16 \pm 0.01)\end{array}$ & $\begin{array}{c}0.15^{\circ} \\
(0.16 \pm 0.01)\end{array}$ \\
\hline
\end{tabular}

Listed are parameter values estimated from fitting the dual-subunit model (Fig. 5) to the average spatial frequency curves of the mean rate in Figure $4 d$. Because firing rate cannot be negative, averaging the curves of many cells will lead to an underestimate of the integrated strength of the mean-decreasing mechanism. For this reason the mean values of the parameters $( \pm \mathrm{SD})$ estimated from the 13 tuning curves used to construct the average ones are given in parentheses. Recall that integrated excitatory strength is the sum of the strengths of large (mean-increasing) subunits and small (mean-decreasing) subunit surrounds.

$$
\begin{aligned}
N(v, f) & =N_{\mathrm{E}}(v, f)+N_{\mathrm{I}}(v, f) \\
& =K_{\mathrm{E}}(f) \exp \left(-\pi^{2} v^{2} R_{\mathrm{E}}(f)^{2}\right)-K_{\mathrm{I}_{\mathrm{c}}}(f) \exp \left(-\pi^{2} v^{2} R_{\mathrm{I}_{\mathrm{c}}}(f)^{2}\right),
\end{aligned}
$$

where $K_{\mathrm{E}}=K_{\mathrm{E}_{\mathrm{C}}}+K_{\mathrm{I}_{\mathrm{S}}}$ and $R_{\mathrm{E}}=R_{\mathrm{E}_{\mathrm{C}}}+R_{\mathrm{I}_{\mathrm{s}}}$. We could not determine with certainty whether the output of the meanchanging mechanisms combines additively or multiplicatively with the signal that sets the resting rate of ganglion cells. Both forms yielded qualitatively similar results, so the model assumes the former for simplicity. As such, the dependence of the mean firing rate $M$ of a ganglion cell on remote spatiotemporal frequency is given by:

$$
M(v, f)=M_{\mathrm{R}}+N(v, f),
$$

where $M_{\mathrm{R}}$ is the resting rate of the cell.

Equation 4 was fitted to spatial frequency curves of the mean rate for each cell and the group average (Fig. 4, thick lines) using SigmaPlot (Jandel Scientific Software, San Rafael, CA), which uses the Marquardt-Levenberg algorithm for regression. The goodness of fit, as assessed by $R^{2}$, exceeded 0.93 in every case unless the tuning curve was nearly flat or clipped at zero. Parameter values of the best fit are listed in Table 1 . Note that model estimates of excitatory strength reflect not just the contributions of mean-increasing subunits but also those of the surround of mean-decreasing subunits because they operate over the same spatial frequencies. Strength estimates should also be viewed as lower bounds on the true values because our stimulus excludes possible contributions from mean-changing subunits residing inside the classical receptive field and outside the limits of the visual display (see below).

Inspection of Table 1 reveals that remote temporal frequency had little effect on subunit radius but that it had a large effect on their integrated strength. That is, excitatory strength rose from $\sim 26$ ips at $0.25 \mathrm{~Hz}$ to $\sim 52$ ips at $4 \mathrm{~Hz}$, while inhibitory strength fell from $\sim 27$ to $\sim 15$ ips. This does not necessarily mean that the mean firing rate actually changed by these amounts because the mean-increasing and mean-decreasing mechanisms act in opposition. However, cells like the ones in Figure 5, $b$ and $c$, demonstrate that such strengths are not unreasonable.

Figure 6 plots the integrated strength and subunit radius of the mean-changing mechanisms for $1 \mathrm{~Hz}$ gratings as a function of the

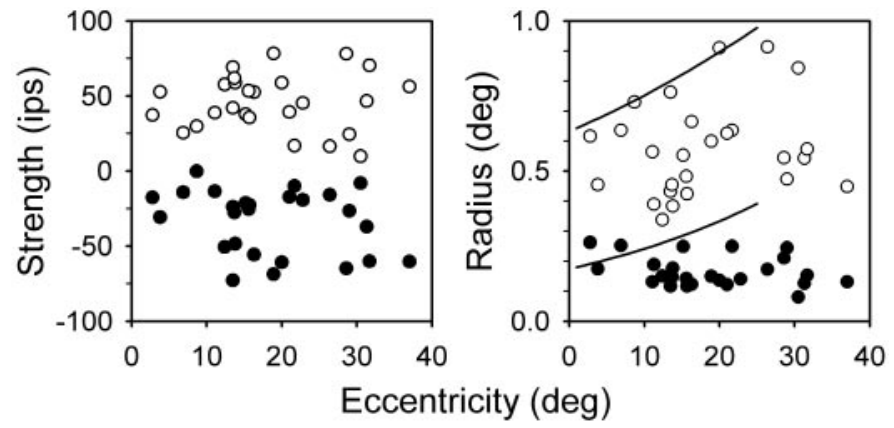

Figure 6. Subunit properties do not depend on retinal location. The integrated strength (left) and subunit radii (right) of the mean-increasing (open circles) and mean-decreasing ( filled circles) mechanisms are plotted against the eccentricity of recorded Y-cells $(n=25)$. Trends in the data are weak at best. Linear regression estimated the mean-increasing subunit radius, for example, to grow by $\sim 25 \%$ over $30^{\circ}$ of eccentricity, which is not much larger than the variability in subunit radius at a given eccentricity. Disk diameter, $10-15^{\circ}$; grating contrast and temporal frequency, $50 \%$ and $1 \mathrm{~Hz}$, respectively. The lower and upper solid lines plot the regression fits of Linsenmeier et al. (1982) for the X-and Y-cell center radius, respectively, as a function of retinal eccentricity. deg, Degree.

retinal location of recorded cells. There appears to be little if any dependence of these parameters on retinal eccentricity over the $\sim 5$ to $40^{\circ}$ range of our measurements. Any trends are masked by subunit-to-subunit variability. That subunit radius depended weakly on cell location contrasts with the center radius of ganglion cells (solid lines), which is known to increase with eccentricity (Cleland et al., 1979; Linsenmeier et al., 1982). This implies either that mean-changing subunits of a given type are the same size throughout the retina or that subunits in one region overwhelmed the contributions of all others. Such a regional bias might be expected because the density of most retinal neurons increases toward the area centralis (for review, see Wässle and Boycott, 1991). We do not believe this to be the case because the remote gratings were limited in spatial extent. Hence, different populations of subunits should have been active in the most central and peripheral cells recorded, yet subunit radius remained approximately the same. In agreement with our findings, Derrington et al. (1979) present evidence that frequency-doubling subunits also do not vary in size with retinal location.

Quantifying subunit radius was ultimately the main purpose of the model. Because the estimates did not depend much on temporal frequency or retinal eccentricity, all were averaged together. The average radius of the mean-increasing subunits was $0.61 \pm 0.22^{\circ}$ (mean $\left.\pm \mathrm{SD}\right)$, which lies within the upper range of center radii for $\mathrm{X}$-cells and the lower range for Y-cells (Fig. 6) (Cleland et al., 1979; Linsenmeier et al., 1982; Troy et al., 1993). The average center radius of the mean-decreasing subunits, on the other hand, was $0.16 \pm 0.04^{\circ}$, making them $\sim 15$ times smaller in area. Only X-cells within $5-10^{\circ}$ of the area centralis have center radii typically this small (Cleland et al., 1979). Estimates of center and surround radii for mean-decreasing subunits also compared well with those for frequency-doubling subunits. Their center and surround radii averaged $0.20 \pm 0.07$ and $1.09 \pm 0.81^{\circ}$, respectively, based on difference-of-Gaussian fits of second-harmonic tuning curves (e.g., Fig. $2 d$, solid lines) of a sample of 9 Y-cells. Others have reported center and surround radii of $0.22 \pm 0.01$ and $0.63 \pm 0.33^{\circ}$ for the frequency-doubling subunits (So and Shapley, 1981), lending quantitative support to the idea that mean-increasing subunits and frequency-doubling subunits may be related. 
a

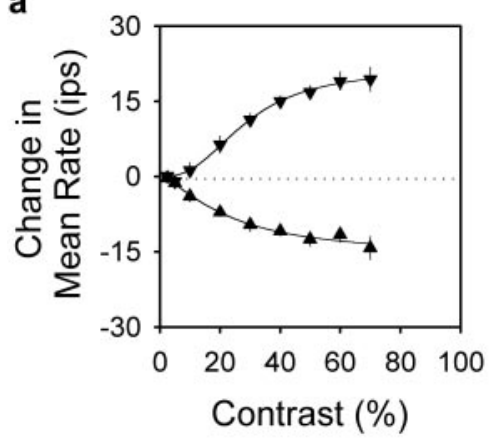

b

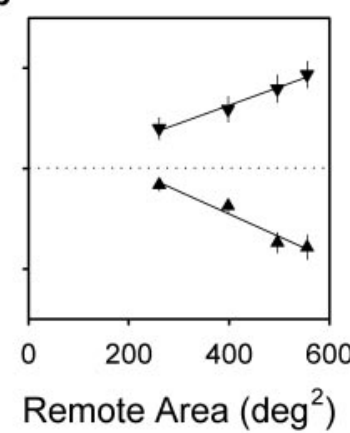

Figure 7. Remote effects on mean rate require moderate-to-high contrast stimulation of widespread areas of the retina. $a$, Average mean rate change of 15 Y-cells for $0.1 \mathrm{cpd}$ (downward triangles) and $1 \mathrm{cpd}$ (upward triangles) remote gratings of different contrast. Thin lines plot the best fit of a Naka-Rushton type of equation $\left(M=M_{\infty}\left[C^{\mathrm{x}} /\left[C^{\mathrm{x}}+C_{0.5}{ }^{\mathrm{x}}\right)\right]\right)$ to the data. $M_{\infty}$, the maximum change in mean rate, was 21 and -16 ips for the 0.1 and $1 \mathrm{cpd}$ grating, respectively. $C_{0.5}$, the contrast at half mean-rate saturation, was 28 and $23 \%$. And, $x$ was 2.6 and 1.5. Disk diameter, $10-15^{\circ} . b$, Average mean rate change of 14 Y-cells for remote gratings covering different amounts of the display. Remote area equals display area $\left(600 \mathrm{deg}^{2}\right)$ minus disk area. Symbols are the same as in $a$. Thin lines are linear regression fits of the data. Error bars indicate SEMs. Grating contrast, $50 \%$.

\section{The mean-changing mechanisms require large patterns of moderate-to-high contrast to activate}

The effect of remote drifting gratings on mean rate depended not only on their spatiotemporal frequency but also on their contrast and spatial extent. Figure $7 a$ plots the average contrast response function of the mean rate for $15 \mathrm{Y}$-cells for $0.1 \mathrm{cpd}$ (downward triangles) and $1 \mathrm{cpd}$ (upward triangles) remote gratings drifting at $1 \mathrm{~Hz}$. Grating contrast generally had to exceed $\sim 10 \%$ for us to detect mean rate changes. Because most ganglion cells respond strongly to gratings of such contrast when drifted over their receptive field center or surround (Fig. 2b), the mean-changing mechanisms appear less responsive to contrast than are the classical mechanisms. They also have more narrow operating ranges because mean rate changes generally saturated at $\sim 50 \%$ contrast. To determine the peak and half-saturation point of the effect of contrast on mean rate, the data in Figure $7 a$ were fitted with a Naka-Rushton type of equation (thick lines). Rate changes induced by the 0.1 and $1 \mathrm{cpd}$ remote gratings saturated at 21 and -16 ips on average, in agreement with Figure $4 d$ from a largely different group of cells. The half-saturation point was reached at 28 and $23 \%$ contrast, respectively.

To examine the spatial pooling of subunit signals, the disk used to mask the receptive field center and surround was varied in diameter. For most cells the disk could be no smaller than $5^{\circ}$ in diameter without generating strongly modulated responses from the surround. Figure $7 b$ plots, as a function of remote stimulus area, the average mean rate of 14 Y-cells for $0.1 \mathrm{cpd}$ (downward triangles) and $1 \mathrm{cpd}$ (upward triangles) remote gratings drifting at $1 \mathrm{~Hz}$. Mean rate increases and decreases induced by the respective gratings were both largest for the smallest disk, which suggests that mean-changing subunits extend at least partway into the classical receptive field. Decreasing remote stimulus area by increasing disk diameter returned the mean rate toward its resting value in an approximately linear manner. This implies that subunit signals were more or less equal over the region investigated. That is, subunits located $5^{\circ}$ from the receptive field center seemed to have the same strength as ones $20^{\circ}$ from it. Further attempts to

determine the full extent of the mean-changing mechanisms by moving the display were not pursued. But, given that reversing gratings positioned $>40^{\circ}$ from the receptive field can evoke frequency-doubled responses from ganglion cells (Krüger and Fischer, 1973), mean-changing mechanisms may be expected to span a comparably large region of the retina. Hence, these mechanisms must pool signals from lots of subunits. Just in the region covered by our remote gratings, our radius estimates indicate that hundreds to thousands of them must have been involved in the observed effects of remote gratings on mean firing rate.

\section{DISCUSSION}

Our results indicate that cat retinal ganglion cells, particularly Y-cells, receive input from at least two nonlinear mechanisms that pool signals from many rectifying subunits residing outside the classical receptive field. One of these mechanisms excites ganglion cells and the other inhibits them, as evidenced by sustained increases or decreases in their firing rate to remote drifting gratings of different spatiotemporal frequency. The mean-increasing mechanism uses nonlinear subunits having better temporal resolution than those of the mean-decreasing mechanism but worse spatial resolution. Both have narrow operating ranges, requiring 10-20\% contrast to activate and saturating at moderate-to-high stimulus contrast. On the basis of receptive field size and shape, the mean-decreasing subunits bear closest resemblance to the frequency-doubling subunits known from previous work. Because the latter appear excitatory to ganglion cells, we presume that the mean-decreasing and frequencydoubling mechanisms relay signals from the same subunits to ganglion cells via different pathways. Figure 8 incorporates the various nonlinear subunits into a picture of the ganglion cell receptive field.

\section{Relation to previous studies of mammalian ganglion cells using continuous remote stimulation}

The introductory remarks highlighted seemingly contradictory findings regarding the effect of remote patterns that continuously move. Consideration of the stimulus paradigms used in the context of our results helps reconcile matters. McIlwain (1964) first showed that waving a $3^{\circ}$ or larger disk at $20-60^{\circ} / \mathrm{sec}$ outside the classical receptive field increased the mean rate of cat ganglion cells. This stimulus contains power mostly in the range of $0-0.3 \mathrm{cpd}$ and $3-10 \mathrm{~Hz}$, which should strongly activate the mean-increasing mechanism (Fig. 4). Subsequent studies reported that blotches (Levick et al., 1964; Fischer and Krüger, 1980; Krüger, 1980), windmills (Moors et al., 1974; EnrothCugell and Jakiela, 1980), and gratings (Jakiela, 1978; EnrothCugell and Jakiela, 1980) also elevated the mean rate when set in motion. The blotches must have generated all kinds of spatiotemporal frequencies, so a rise in mean rate is not surprising. The mean-increasing mechanism is generally more potent than the mean-decreasing one (Table 1). The windmills should also have driven the mean-increasing subunits preferentially well in the above studies because they contained spatial frequencies ranging from 0.05 to $0.3 \mathrm{cpd}$ and 0.01 to $4.8 \mathrm{cpd}$ and were spun at $1-3$ and $9 \mathrm{~Hz}$, respectively. The gratings, on the other hand, produced mixed effects in the above studies. Two cells increased their mean rate and two others decreased it. This, however, is entirely consistent with our results because the former cells viewed 0.25 or 0.5 cpd remote gratings drifting at $2-9 \mathrm{~Hz}$ and the latter ones viewed a 1 cpd grating drifting at $0.5-1 \mathrm{~Hz}$. The effect of remote gratings 


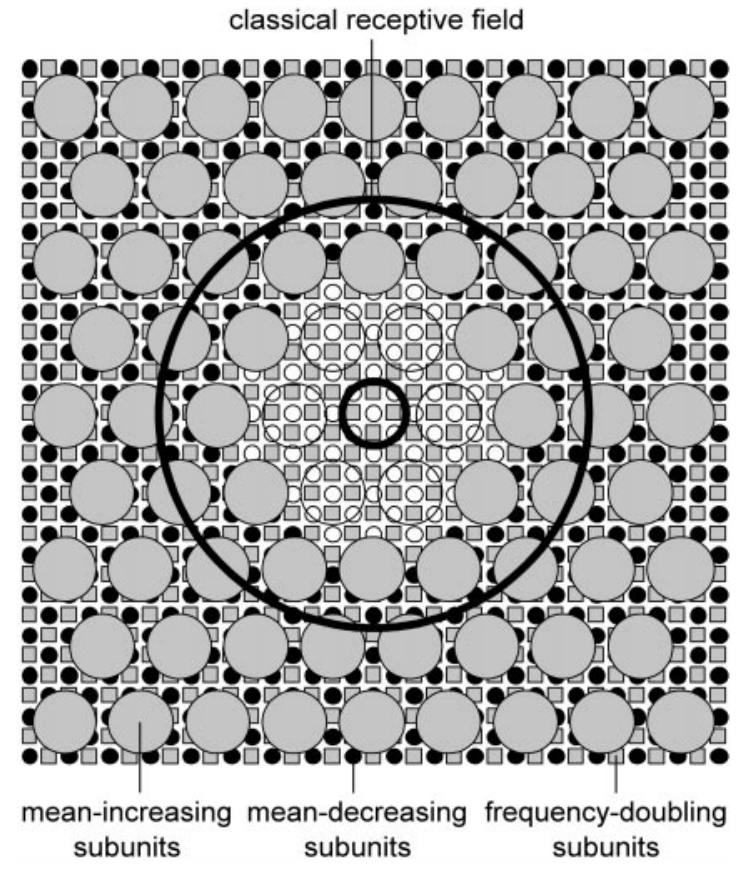

Figure 8. The ganglion cell receptive field. This field consists of the familiar center-surround mechanisms (thick lines) and three nonlinear mechanisms. These mechanisms are more potent in Y-cells than in $\mathrm{X}$-cells. They appear to operate by rectifying input from large or small subunits distributed over widespread regions of the retina. For purpose of illustration the figure depicts individual subunits, but they should be collectively viewed as a sheet because no one of them can evoke a response from the cell. The large subunits subserve a mechanism that acts to increase the mean rate during continuous background stimulation (large gray circles), whereas, the small subunits appear to subserve two mechanisms, one that acts to decrease mean rate during such stimulation (small black circles) and one known from previous work to generate frequency-doubled responses to back-and-forth movements of large patterns (small gray squares). The latter mechanism may also contribute to mean rate changes, but its contribution would be small compared with the mean-decreasing mechanism, at least for stimuli moving outside the classical receptive field. The various subunits are shaded gray or black to indicate whether they have an excitatory or inhibitory effect on ganglion cells, respectively. Those not shaded are presumed to exist, but we could not probe the central portion of the receptive field to confirm this (see Results for explanation). All receptive field elements are drawn to scale for a Y-cell. For reference, the small subunits are $0.3^{\circ}$ in diameter. Their surrounds are not depicted in the figure.

was also striking, changing the mean rate by $30-50$ ips in each case.

Perhaps less amenable to our findings are reported increases in ganglion cell firing rate with full-field drifting gratings of high spatial frequency (Enroth-Cugell and Robson, 1966; Cleland et al., 1971). This might reflect possible mean rate contributions from frequency-doubling subunits (see legend of Fig. 8) if they were more potent than mean-decreasing subunits under full-field stimulus conditions. Another factor might have been the drift frequency $(2-4 \mathrm{~Hz})$, which was not optimal for the meandecreasing mechanism (Fig. 4). Alternatively, we and others (Jakiela, 1978; Smirnakis et al., 1997) have noticed that the mean rate can take tens of seconds to recover to its resting level after high contrast stimulation. It may thus creep upward in marching from low to high spatial frequency, as in Cleland et al. (1971), their Figure 2, if pause is not given between steps for the meanincreasing mechanism to inactivate.
Suppressed-by-contrast

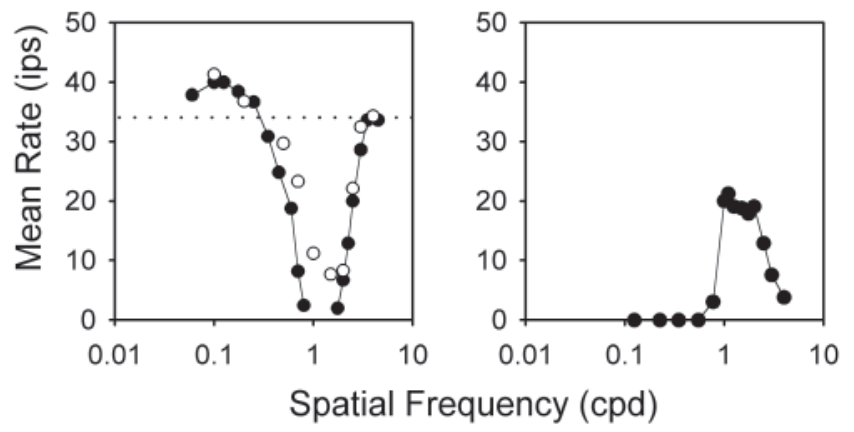

Figure 9. The nonlinear receptive field of X-and Y-cells closely resembles that of other types of ganglion cells. Plotted are the spatial frequency curves of the mean rate for a suppressed-by-contrast (left; filled circles) and impressed-by-contrast (right; filled circles) cell to full-field gratings drifting at $1 \mathrm{~Hz}$ (from Troy et al., 1989) and for a Y-cell (left; open circles) to remote gratings drifting at the same frequency. This particular Y-cell was chosen because it had the same resting firing rate (dotted line) and came from approximately the same eccentricity as the suppressed-bycontrast cell. Grating contrast, $50 \%$.

\section{Corroborative evidence of mean-changing mechanisms of opposite polarity in the retina}

The validity of our results is supported by rarely encountered types of cat ganglion cell that are excited or suppressed by contrast of either polarity (Rodieck, 1967; Stone and Hoffman, 1972; Cleland and Levick, 1974; Mastronarde, 1985). These cells exhibit no response to drifting gratings except for a change in mean rate (Troy et al., 1989). Spatial frequency curves of the mean rate closely resemble those reported here (Fig. 9). Were it not for the center-surround organization of recorded cells and their high incidence, they could have passed for suppressed-bycontrast cells. Additional support can be found in fish retina. Sugawara (1985) reports that remote windmills spun at slow velocities reduced the mean rate of most carp ganglion cells, whereas those spun at high velocities elevated it. One-vane patterns were more effective than four-vane patterns at high spin velocities and vice versa at low spin velocities. Other animals besides cat thus use large fast mean-increasing subunits and small slow mean-decreasing subunits in their retina.

\section{Implications for retinal circuitry}

Victor and Shapley (1979) proposed that nonlinear subunits correspond to bipolar cell signals rectified at bipolar $\rightarrow$ amacrine cell synapses. Evidence of nonlinear behavior at these synapses is ample (Werblin, 1977; Kujiraoka et al., 1988). If so, our results imply that the receptive field centers of bipolar cells are $\sim 65$ and $\sim 250 \mu \mathrm{m}$ in diameter, primarily independent of retinal location, based on the retinal magnification factor of Hughes (1976) of 200 $\mu \mathrm{m}$ per degree. The paucity of cat bipolar cell recordings makes this difficult to verify. But, known cell types have dendritic trees ranging from 30 to $100 \mu \mathrm{m}$ in diameter, and at least one type varied little with eccentricity (Kolb et al., 1981). Because dendritic tree size has been found to underestimate center size in bipolar cells (Nelson et al., 1981; Nelson and Kolb, 1983; Dacey et al., 2000), mean-decreasing subunits may be small bipolar cells. Recent evidence that primate bipolar cells have strong surrounds lends support to this hypothesis (Dacey et al., 2000). Meanincreasing subunits might be large bipolar cells or perhaps small-field amacrine cells. These amacrine cells have the appropriate center size, and most lack antagonistic surrounds 
(Kolb and Nelson, 1996). Rectification would then transpire at amacrine $\rightarrow$ amacrine cell synapses.

Wide-field amacrine cells presumably pool subunit signals and relay them across the retina. Most studies have found these cells to depolarize transiently at light onset and offset (Kaneko, 1973; Toyoda et al., 1973; Naka, 1977; Werblin, 1977; Marchiafava and Torre, 1978), but hyperpolarizing ones have been seen (Ammermüller and Kolb, 1995; Burkhardt and Fahey, 1999; Demb et al., 1999). This behavior appears to result from phasic input from ON- and OFF-center bipolar cells (Slaughter and Miller, 1981). In mammals, ON-OFF amacrine cells have large dendritic trees that stratify between the ON- and OFF-sublaminas of the inner plexiform layer and long axon-like processes that traverse millimeters of retina (Dacheux and Raviola, 1995; Freed et al., 1996; Stafford and Dacey, 1997). All have so far exhibited broad receptive fields that lacked antagonistic surrounds. The Gaussian diameter of the field, measured by varying the position of a modulated bar, ranged from 0.5 to $2 \mathrm{~mm}$ in cat (Freed et al., 1996), which amounts to $2-10^{\circ}$ of visual angle (Hughes, 1976). Because their dendritic trees span a four times smaller region, pooling of subunit input presumably involves their axon-like processes or gap junctions that may connect them (Kolb and Nelson, 1985). Figure 10 incorporates these cells into a simple circuit that can account for our results.

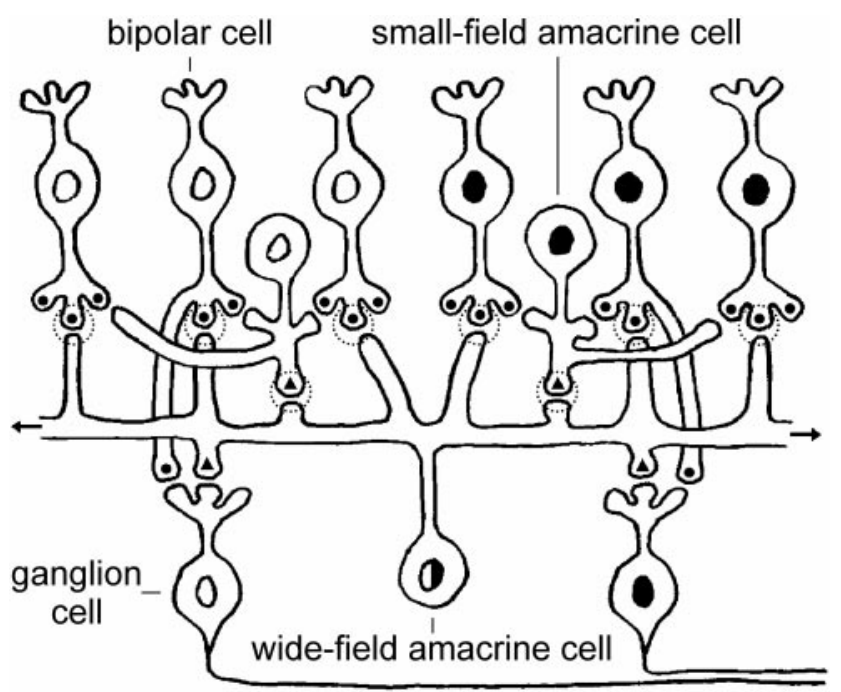

Figure 10. Schematic circuit for generating mean rate changes in ganglion cells during remote stimulation. The circuit assumes that amacrine cells form inhibitory chemical synapses (Pourcho and Goebel, 1983). As such, wide-field ON-OFF amacrine cells (black-and-white nucleus) rectify input from ON- and OFF-center (white and black nuclei, respectively) bipolar cells and small-field amacrine cells within their dendritic tree and transmit the pooled result to ON- and OFF-center ganglion cells throughout the retina via their long axon-like processes. The transmission is partially mediated by spikes (Cook et al., 1998; Demb et al., 1999); electrical connections between wide-field amacrine cells may also be involved (Naka and Christensen, 1981; Kolb and Nelson, 1985). This wide-field amacrine cell pathway would constitute the nonclassical receptive field of ganglion cells. The classical receptive field presumably derives from the bipolar-ganglion cell pathway depicted in the figure. Filled circles and triangles indicate excitatory and inhibitory synaptic transmission, respectively. Dotted circles indicate rectifying synapses. Note that the somata of wide-field amacrine cells are found in the inner plexiform and inner nuclear layers in addition to the ganglion cell layer (Stafford and Dacey, 1997).

\section{Functional relevance of remote effects on mean firing rate}

The mean firing rate of retinal ganglion cells is thought to reflect the balance of tonic input from their receptive field center and surround (Barlow and Levick, 1969). Our results show that excitatory and inhibitory nonlinear receptive field mechanisms also factor into the mean rate equation. These mechanisms can be remarkably potent in Y-cells, raising or lowering the mean rate by 40 ips or more, but they are comparatively weak in X-cells. One of their functions may be to switch the retina between $\mathrm{X}$ - and Y-based modes of information transmission as cats interact with their surroundings. Tasks involving slow movements in high spatial frequency environments will tend to suppress Y-cell signals, whereas tasks involving fast movements in low spatial frequency environments will tend to enhance them. Consider, for example, a cat sneaking up on a field mouse in a sunlit meadow. The cat's slow motion should preferentially activate mean-decreasing subunits and essentially turn off the Y-cell population. Because these cells have lower spatial resolution than X-cells and transient responses, they presumably are not needed under such circumstances. This may be desirable for computational or metabolic reasons. If the mouse tries to escape, however, the ensuing chase should activate mean-increasing subunits and turn the Y-cell population back on. Because these cells have somewhat higher temporal resolution than X-cells, they could help the cat track the motion of the target and thereby catch it. Another function of mean-changing mechanisms may be to convey the setting of retinal contrast gain controls to the brain. These gain controls dynamically alter the transfer characteristics of ganglion cells, making their responses more transient by attenuating sustained response components (Shapley and Victor, 1978). The gain adjustments help avert response saturation and thereby extend the range of retinal output. Mean rate changes provide a signal that recipient neurons in the brain could then use to account for contrast gain adjustments in each ganglion cell.

\section{REFERENCES}

Ammermüller J, Kolb H (1995) The organization of the turtle inner retina I. ON- and OFF-center pathways. J Comp Neurol 358:1-34.

Barlow HB (1953) Summation and inhibition in the frog's retina. J Physiol (Lond) 119:69-88.

Barlow HB, Levick WR (1969) Changes in the maintained discharge with adaptation level in the cat retina. J Physiol (Lond) 202:699-718.

Barlow HB, Derrington AM, Harris LR, Lennie P (1977) The effects of remote retinal stimulation on the responses of cat retinal ganglion cells. J Physiol (Lond) 269:177-194.

Benardete EA, Kaplan E (1999) The dynamics of primate M retinal ganglion cells. Vis Neurosci 16:355-368.

Bohnsack DL, Troy JB (1997) VSApc: a C++ package for quantitative extracellular single-cell electrophysiology. Spat Vis 11:95-98.

Burkhardt DA, Fahey PK (1999) Contrast rectification and distributed encoding by ON-OFF amacrine cells in the retina. J Neurophysiol 261:1676-1688.

Caldwell JH, Daw NW (1978) New properties of rabbit retinal ganglion cells. J Physiol (Lond) 276:257-276.

Cleland BG, Levick WR (1974) Properties of rarely encountered types of ganglion cells in the cat's retina and an overall classification. J Physiol (Lond) 240:457-492.

Cleland BG, Dubin MW, Levick WR (1971) Sustained and transient neurones in the cat's retina and lateral geniculate nucleus. J Physiol (Lond) 217:473-496.

Cleland BG, Harding TH, Tulunay-Keesey U (1979) Visual resolution and receptive field size: examination of two kinds of cat retinal ganglion cell. Science 205:1015-1017.

Cook PB, Lukasiewicz PD, McReynolds JS (1998) Action potentials are required for the lateral transmission of glycinergic transient inhibition in the amphibian retina. J Neurosci 18:2301-2308.

Dacey D, Packer OS, Diller L, Brainard D, Peterson B, Lee B (2000) Center surround receptive field structure of cone bipolar cells in primate retina. Vision Res 40:1801-1811. 
Dacheux RF, Raviola E (1995) Light responses from one type of ONOFF amacrine cells in the rabbit retina. J Neurophysiol 74:2460-2468.

Demb JB, Haarsma L, Freed MA, Sterling P (1999) Functional circuitry of the retinal ganglion cell's nonlinear receptive field. J Neurosci 19:9756-9767.

Derrington AM, Lennie P, Wright MJ (1979) The mechanism of peripherally evoked responses in retinal ganglion cells. J Physiol (Lond) 289:299-310

Enroth-Cugell C, Freeman AW (1987) The receptive-field spatial structure of cat retinal Y cells. J Physiol (Lond) 384:49-79.

Enroth-Cugell C, Jakiela HG (1980) Suppression of cat retinal ganglion cell responses by moving patterns. J Physiol (Lond) 302:49-72.

Enroth-Cugell C, Robson JG (1966) The contrast sensitivity of retinal ganglion cells of the cat. J Physiol (Lond) 187:517-552.

Enroth-Cugell C, Robson JG, Schweitzer-Tong DE, Watson AB (1983) Spatiotemporal interactions in cat retinal ganglion cells showing linear spatial summation. J Physiol (Lond) 341:279-307.

Fischer B, Krüger J (1980) Continuous movement of remote patterns and shift-effect of cat retinal ganglion cells. Exp Brain Res 40:229-232.

Flecknell P (1996) Laboratory animal anaesthesia. San Diego: Academic.

Freed MA, Pflug R, Kolb H, Nelson R (1996) ON-OFF amacrine cells in cat retina. J Comp Neurol 364:556-566.

Freeman AW (1991) Spatial characteristics of the contrast gain control in the cat's retina. Vision Res 31:775-785.

Hochstein S, Shapley RM (1976a) Quantitative analysis of retinal ganglion cell classifications. J Physiol (Lond) 262:237-264.

Hochstein S, Shapley RM (1976b) Linear and nonlinear spatial subunits in Y cat retinal ganglion cells. J Physiol (Lond) 262:265-284.

Hughes A (1976) A supplement to the cat schematic eye. Vision Res 16:149-154.

Ikeda H, Wright MJ (1972) Functional organization of the periphery effect in retinal ganglion cells. Vision Res 12:1857-1879.

Jakiela HG (1978) The effect of retinal image motion on the responsiveness of retinal ganglion cells in the cat. PhD thesis, Northwestern University.

Kaneko A (1973) Receptive field organization of bipolar and amacrine cells in the goldfish retina. J Physiol (Lond) 235:133-153.

Kolb H, Nelson R (1985) Functional neurocircuitry of amacrine cells in the cat retina. In: Neurocircuitry of the retina: a Cajal memorial (Gallego A, Gouras P, eds), pp 215-232. Amsterdam: Elsevier.

Kolb H, Nelson R (1996) Hyperpolarizing, small-field, amacrine cells in cone pathways of cat retina. J Comp Neurol 371:415-436.

Kolb H, Nelson R, Mariani A (1981) Amacrine cells, bipolar cells and ganglion cells of the cat retina: a Golgi study. Vision Res 21:1081-1114.

Krüger J (1980) The shift-effect enhances X- and suppresses Y-type response characteristics of cat retinal ganglion cells. Brain Res 201:71-84.

Krüger J, Fischer B (1973) Strong periphery effect in cat retinal ganglion cells. Excitatory responses in ON- and OFF-center neurones to single grid displacements. Exp Brain Res 18:316-318.

Kuffler SW (1953) Discharge patterns and functional organization of mammalian retina. J Neurophysiol 16:37-68.

Kujiraoka T, Saito T, Toyoda J (1988) Analysis of synaptic inputs to ON-OFF amacrine cells of the carp retina. J Gen Physiol 92:475-487.

Levick WR (1972) Another tungsten microelectrode. Med Biol Eng 10:510-515.

Levick WR, Oyster CW, Davis DL (1964) Evidence that McIlwain's periphery effect is not a stray light artifact. J Neurophysiol 28:555-557.

Linsenmeier RA, Frishman LJ, Jakiela HG, Enroth-Cugell C (1982) Receptive field properties of $\mathrm{X}$ and $\mathrm{Y}$ cells in the cat retina derived from contrast sensitivity measurements. Vision Res 22:1173-1183.

Marchiafava PL, Torre V (1978) The responses of amacrine cells to light and intracellularly applied currents. J Physiol (Lond) 276:83-102.

Mastronarde DN (1985) Two types of cat retinal ganglion cells that are suppressed by contrast. Vision Res 25:1195-1196.

McIlwain JT (1964) Receptive fields of optic tract axons and lateral geniculate cells: peripheral extent and barbiturate sensitivity. J Neurophysiol 27:1154-1173.

Moors J, Coenen AML, Gerits HJM, Vendrik AJH (1974) The filling-in phenomenon in vision and McIlwain's periphery effect. Exp Brain Res 19:343-350.

Naka KI (1977) Functional organization of catfish retina. J Neurophysiol 40:26-43.

Naka KI, Christensen BN (1981) Direct electrical connections between transient amacrine cells in the catfish retina. Science 214:462-464.
Nelson R, Kolb H (1983) Synaptic patterns and response properties of bipolar and ganglion cells in the cat retina. Vision Res 23:1183-1195.

Nelson R, Kolb H, Robinson MM, Mariani AP (1981) Neural circuitry of the cat retina: cone pathways to ganglion cells. Vision Res 21:1527-1536.

Noda H, Adey WR (1974) Retinal ganglion cells of the cat transfer information on saccadic eye movement and quick target motion. Brain Res 70:340-345.

Pourcho RG, Goebel DJ (1983) Neuronal subpopulations in cat retina which accumulate the GABA agonist, $\left[{ }^{3} \mathrm{H}\right]$ muscimol: a combined Golgi and autoradiographic study. J Comp Neurol 219:25-35.

Rapaport DH, Stone J (1988) The periphery effect in cat retinal ganglion cells: variation with functional class and eccentricity. Exp Brain Res 70:73-78.

Rodieck RW (1965) Quantitative analysis of cat retinal ganglion cell response to visual stimuli. Vision Res 5:583-601.

Rodieck RW (1967) Receptive fields in the cat retina: a new type. Science 157:90-92.

Schwartz EA (1973) Organization of ON-OFF cells in the retina of the turtle. J Physiol (Lond) 230:1-14.

Shapley RM, Victor JD (1978) The effect of contrast on the transfer properties of cat retinal ganglion cells. J Physiol (Lond) 285:275-298.

Shapley RM, Victor JD (1979) Nonlinear spatial summation and the contrast gain control of cat retinal ganglion cells. J Physiol (Lond) 290:141-161.

Slaughter MM, Miller RF (1981) 2-Amino-4-phosphonobutyric acid: a new pharmacological tool for retina research. Science 211:182-184.

Smirnakis SM, Berry MJ, Warland DK, Bialek W, Meister M (1997) Adaptation of retinal processing to image contrast and spatial scale. Nature 386:69-73.

So YT, Shapley RM (1981) Spatial tuning of cells in and around lateral geniculate nucleus of the cat: $\mathrm{X}$ and $\mathrm{Y}$ relay cells and perigeniculate interneurons. J Neurophysiol 45:107-120.

Stafford DK, Dacey DM (1997) Physiology of the A1 amacrine: a spiking, axon-bearing interneuron of the macaque monkey retina. Vis Neurosci 14:507-522.

Stone J, Hoffman KP (1972) Very slow-conducting ganglion cells in the cat's retina: a major, new functional type? Brain Res 43:610-616.

Sugawara K (1985) Lateral actions at the inner plexiform layer of the carp retina: effects of turning windmill pattern stimulus. Vision Res 25:1179-1186.

Thibos LN, Werblin FS (1978) The properties of surround antagonism elicited by spinning windmill patterns in the mudpuppy retina. J Physiol (Lond) 278:101-116.

Toyoda J, Hashimoto H, Ohtsu K (1973) Bipolar-amacrine transmission in the carp retina. Vision Res 13:295-307.

Troy JB, Enroth-Cugell C (1993) X and Y ganglion cells inform the cat's brain about contrast in the retinal image. Exp Brain Res 93:383-390.

Troy JB, Robson JG (1992) Steady discharges of X and Y retinal ganglion cells of cat under photopic illuminance. Vis Neurosci 9:535-553.

Troy JB, Einstein G, Schuurmans RP, Robson JG, Enroth-Cugell C (1989) Responses to sinusoidal gratings of two types of very nonlinear retinal ganglion cells of cat. Vis Neurosci 3:213-223.

Troy JB, Oh JK, Enroth-Cugell C (1993) Effect of ambient illumination on the spatial properties of the center and surround of Y-cell receptive fields. Vis Neurosci 10:753-764.

Troy JB, Schweitzer-Tong DE, Enroth-Cugell C (1995) Receptive-field properties of $\mathrm{Q}$ retinal ganglion cells of the cat. Vis Neurosci $12: 285-300$.

Troy JB, Bohnsack DL, Diller LC (1999) Spatial properties of the cat $\mathrm{X}$-cell receptive field as a function of mean light level. Vis Neurosci 16:1089-1104.

Victor JD (1987) The dynamics of the cat retinal X cell centre. J Physiol (Lond) 386:219-246.

Victor JD, Shapley RM (1979) The nonlinear pathway of Y ganglion cells in the cat retina. J Gen Physiol 74:671-689.

Wässle H, Boycott BB (1991) Functional architecture of the mammalian retina. Physiol Rev 71:447-480.

Watanabe J, Tasaki K (1980) Shift-effect in the rabbit retinal ganglion cells. Brain Res 181:198-201.

Werblin F (1972) Lateral interactions at inner plexiform layer of vertebrate retina: antagonistic responses to change. Science 175:1008-1010.

Werblin F (1977) Regenerative amacrine cell depolarization and formation of ON-OFF ganglion cell response. J Physiol (Lond) 264:767-785.

Werblin F, Copenhagen DR (1974) Control of retinal sensitivity. III. Lateral interactions at the inner plexiform layer. J Gen Physiol 63:88110 . 